\title{
PRAVNA ZNANOST KAO IZVOR GRAĐANSKOG PRAVA
}

\author{
Prof. dr. sc. Aldo Radolović*
}

\author{
UDK.: 340.143:347 \\ https://doi.org/10.30925/zpfsr.41.1.8 \\ Ur.: 3. veljače 2020. \\ Pr.: 17. veljače 2020. \\ Prethodno priopćenje
}

\begin{abstract}
Sažetak
Znanost građanskog prava u građanskom se pravu navodi kao sporedan, „posredan", gotovo manje važan izvor građanskog prava. Neke novije tendencije, kažu suprotno, da je znanost građanskog prava prvi izvor građanskog prava jer sudac sudi prema znanju prava stečenom za vrijeme studija $i$ u kasnijem profesionalnom razvoju. Stoga je razgovor o znanosti građanskog prava kao izvora ove znanosti ujedno i razgovor o obrazovanju pravnika na pravnim fakultetima kao i o produljenju toga procesa nakon završstka studija. U Republici Hrvatskoj u ovom trenutku u oba pravca vidimo znatne probleme pa čak i zaostajanje koje bi bilo poželjno što prije premostiti.
\end{abstract}

Ključne riječi: pravo; građansko pravo; znanost; znanost prava; znanost građanskog prava; izvori građanskog prava; obrazovanje pravnika; studij prava; obrazovanje pravnika i sudaca nakon studija; primjena znanosti građanskog prava u suđenju.

\section{1. $U V O D$}

Malo je pitanja u građanskom pravu koja izazivaju tako različite pa i oprečne reakcije kao što je pitanje znanosti građanskog prava kao izvora građanskog prava. Premda bi se problem, mutatis mutandis, mogao „prenijeti“ i na druge dijelove prava, ovdje ćemo se zadržati samo na problemu koji dotiče građansko pravo (civil) gdje je sam problem izvorno i koncipiran. S jedne strane, tu je „sve jasno“ jer civila i ne bi bilo da nema njegove znanosti. Civil je, dakle, rezultat te znanosti i sve što je civil je (ujedno) i znanost civila. No, s druge strane, stvari ne stoje baš tako i s druge pravne optike promatrano problem je mnogo složeniji, a odgovori nisu potpuno jednostavni. Naime, već prvo „zavirivanje“ u temeljnu udžbeničku materiju pokazat će nam iznenađujuću činjenicu - da u temeljnoj literaturi civila ili nema mnogo riječi o znanosti civila ili se o tome čak uopće ne govori. Marginalizacija problema nosi u sebi i opasnost marginalizacije cjelokupnoga građanskog prava kome onda prijeti neugodna sudbina zastoja i nazadovanja u razvoju.

* Dr. sc. Aldo Radolović, sudac Ustavnog suda Republike hrvatske i redoviti profesor u mirovini, Sveučilište u Rijeci, Pravni fakultet; radolović47@gmail.com 
Građansko je pravo u Hrvatskoj, u svojoj novijoj povijesti (20. i 21. stoljeće) prošlo vrlo težak put. Izredale su se ovdje sustavi i države koje su nametale socijalne vrijednosti koje znanost građanskog prava ne samo da nije osmislila nego ih često nije mogla ni razumjeti (kolektivizacije, nacionalizacije, prisilna zadrugarstva, „organizacije udruženog rada“, samoupravni sporazumi, društveni dogovori itd.). Pritom je, kao što je to u povijesti nekako i uobičajeno, dio znanosti građanskog prava pristajao na apologetiku takvih sustava, vrlo često čak (napose jakom formom i zaglušujućom medijskom prezentacijom) s pretenzijom da je riječ o napose „visokoj znanosti““ (npr. „udruženi rad“). Neki su znanstvenici civila to ponekad činili i u sasvim dobroj vjeri.

Propašću bivše države i bivšeg sustava stvorene su bitne pretpostavke za renesansu građanskog prava i njegove znanosti, ali stvarna sociološka kretanja pokazuju da je novi smjer mnogo lakše proklamirati nego ostvariti. U svakom novom ima uvijek puno starog (hegelovsko načelo „negacije negacije“), a u našem konkretnom slučaju ,najnezgodnije“ je to što su i nova država, odnosno novo društvo zadržali državno-centralistički model upravljanja. Neposredno posljedica toga je nova dominacija birokratske logike gdje se silno traže diplome (papiri) ali ne i znanje. Od toga, razumljivo, uvelike o trpi svaki znanstveni rad, pa tako i znanstveni rad u građanskom pravu. Prisustvujemo fenomenima koji nikad nisu postojali, a nisu bili niti zamislivi (falsificiranje diploma, a što je još gore - i doslovno kupovanje diploma). Na nekim prostorima bivše države „kao gljive poslije kiše“ niču novi pravni fakulteti (Hrvatska, čini se, barem za sada tomu odolijeva, ali pitanje je hoće li i ona „popustiti“), vrlo dvojbene ili (treba li otvoreno reći) potpuno neznatne ili nikakve znanstvene vrijednosti. Ne treba posebno naglašavati da takve pojave (koje postaju sve izraženije i agresivnije) vode ne samo marginalizaciji građanskog prava i njegove znanosti nego su njihova negacija koju hrvatsko društvo mora hitno i energično zaustaviti.

Zanimljivo je uočiti da nam (barem za sada) nije bitno pomogao ni ulazak u Europsku uniju (2013.). Šest godina članstva, doduše, možda nije razdoblje dostatno za puni prihvat novih pravnih vrijednosti, ali nema ni pravih naznaka o tome (koje bi objektivno trebali očekivati). U europskom konvencijskom i komunitarnom pravu, čini se, prevagnuo je anglosaksonski (precedentni) pristup pravu koji, naizgled, svojom visokom formom i visokim stilom izričaja, pretendira da je ujedno i znanost prava, a zapravo koči njezin razvoj te ju „cementira“ na razini ponekad dosta dvojbene znanstvene vrijednosti i, napose, sprječava daljnji slobodni razvoj.

Suvremena civilizacija i inače pokazuje sve manji interes i smisao za znanstveni i umjetnički rad. To ipak ne mora značiti potpuno prepuštanje općem pesimizmu jer je europsko kontinentalno građansko pravo izraslo iz znanosti, temelji se na znanosti i ne bi smjelo dopustiti nestanak ili bitno slabljenje znanosti. To mora vrijediti i za građansko pravo u Hrvatskoj. Nema „hrvatskoga građanskog prava“ nego govorimo o „građanskom pravu u Hrvatskoj“. Time, želimo reći da smo na terenu građanskog prava sastavni dio Europe (pa i ukupnoga razvijenog svijeta) i da moramo slijediti vrijednosti općega značaja. Postojeći zaostatak treba biti razlog za nove i prave napore u pravcu poboljšanja. Nema poboljšanja „samog od sebe“ nego takav cilj zahtijeva 
dosta promišljenih i pravilnih mjera u tom pravcu.

Ovaj rad želi biti mali i skromni napor u želji ,pokretanja novih motora“ koji će građansko pravo u Hrvatskoj polako, ali sigurno voditi prema njegovoj punoj europeizaciji, i prema europeizaciji njegove znanosti.

\section{TEORIJA GRAĐANSKOG PRAVA O PRAVNOJ ZNANOSTI KAO IZVORU GRA円ANSKOG PRAVA}

Nesumnjivo je određeni povijesni apsurd da samo građansko pravo nije posvećivalo veću pažnju razvoju svoje znanosti kao važnog (bitnog) dijela ukupnoga građanskog prava. U vodećoj europskoj literaturi, dakle samoj znanosti građanskog prava, nalazimo vrlo malo (ili čak ništa) o ulozi te znanosti kao izvoru građanskog prava, o tome koliko građani i pravne osobe iz znanosti mogu saznati sadržaj građanskog prava i, napose, o relevantnoj materiji koja će sucu poslužiti kao temelj razrješenja nekoga spornog pravnog odnosa. ${ }^{1} \mathrm{U}$ bivšoj su državi, čini se, samo Stojanović i Gams ${ }^{2}$ nešto o tome govorili, ali bez većih pretenzija da tu ulogu znanosti građanskog prava posebno istaknu.

Tu vrlo zanimljivu pojavu (da, dakle, samo građansko pravo gotovo isključuje vlastitu znanost iz popisa izvora građanskog prava) danas posebno ističe talijanski profesor građanskoga prava Lipari. ${ }^{3}$ On i $\mathrm{Sacco}^{4}$ to objašnjavaju, tzv. procesom statuizacije (tal. statizzazione di diritto) što mi možemo prevesti kao podržavljenje prava koje se nije razvijalo samo u poznatim totalitarnim društvima nego je u priličnoj mjeri zahvatilo i države demokratske pravne tradicije koje su ponesene veličinom svojih kodifikacija 19. stoljeća upale u iluziju pune izvjesnosti državnog prava (tal. certezza di diritto) koja bitno smanjuje potrebu za znanosti kao važnog čimbenika u ukupnom građanskom pravu. Danas, međutim, navodi dalje Lipari, vrijeme pune izvjesnosti građanskog prava više ne postoji. Glavne europske kodifikacije stare su po 200 godina, a život se u međuvremenu jako promijenio. Građansko pravo, za razliku od rimskih početaka (kada, npr. nije bilo ustavnog ni upravnog prava) mora „kohabitirati“ s drugim dijelovima prava, napose s javnim pravom. Praksa europskih sudova, zaključuje Lipari, to zorno potvrđuje čak i da se pozivom na opće standarde konvencijskog i komunitarnog prava sve češće ,preskače“ građansko pravo.

Nama povijesno vrlo blisko austrijsko pravo i danas znanost građanskog prava svodi (samo) na dimenziju tumačenja prava. ${ }^{5}$ Znanost se po tome definira kao eine

1 Navodimo samo nekoliko primjera gdje se u bitnim udžbenicima građanskog prava uopće ne navodi znanost kao izvor toga prava:

Karl Larenz, Allgemeiner Teil des bürgerlichen Rechts, 8. Aufl. (München: C. H. Beck, 1997.)

Otto Palandt, Bürgerliches Gesetzbuch, 61. Aufl. (München: C. H. Beck, 2002.)

Francesco Galgano, Diritto privato (Padova: CEDAM, 1992.).

2 Andrija Gams, Uvod u građansko pravo: Opšti deo (Beograd: Naučna knjiga, 1985.), 11-14;

Dragoljub Stojanović, Uvod u građansko pravo (Beograd: Prosveta, 1984.), 19-25.

3 Nicolò Lipari, „Dottrina e giurisprudenza quali fonti integrate del diritto“, Jus civile br. 4 (2016.): 295.

4 Rodolfo Sacco, Digesto civile. 4 ed. (Torino: Utet, 1991.): 2.

5 Helmut Koziol, Rudolf Welser, Bürgerliches Recht: Bd. I., 13. Aufl. (Wien: Manz, 2006.), 42. 
praktische Wissenschaft. Možda je to odraz jednoga šireg pravnog trenda koji se već dugo vremena razvija napose na anglosaksonskom zapadu. „Pravo“ $i$,pravna znanost“ su po tome jedno te isto i tu važnu činjenicu posebno zapaža Padjen. ${ }^{6}$ Zapravo je na tu činjenicu prethodno u teorijsko-filozofskoj literaturi u bivšoj saveznoj državi naveo i Lukić.7 On je govoreći o „metodologiji prava“ vrlo određeno rekao da se ne može govoriti o „metodologiji“ pravne znanosti (pravne nauke) jer je znanost prava samo jedan dio ukupnog prava.

U važećem Ustavu Republike Hrvatske (čl. 115. st. 3.) navodi se da „sudovi sude na temelju Ustava, zakona, međunarodnih ugovora i drugih važećih izvora prava“. 8 Koji su to „drugi važeći izvori prava“ ostaje za razjasniti. Sudbina „pravne znanosti“ je u tom smislu potpuno neizvjesna. Presude domaćih sudova (a nije mnogo bolje ni kod inozemnih, uključujući i one europske) iznimno rijetko svoje odluke obrazlažu pozivanjem na znanost građanskog prava. Mogli bismo čak reći da toga gotovo ni nema. Na domaćem planu takve su pojave rezultat jednoga, rekli bismo, „stanja duha“ po kojem u pravu postoje dva svijeta (teorija i praksa) koji jedan s drugim ima malo veze ili čak nema nikakve veze. Europsko sudstvo pak jednako postupa zbog drugoga razloga - iz uvjerenja da na njegove odluke već po sebi „visoko znanstvene“ jer ionako „pravo" $\mathrm{i}$,pravna znanost" su jedno te isto.

Zasluga je metodologije prava ${ }^{9}$ to da je ukazala na više dimenzija sudjelovanja znanosti prava u stvaranju i primjeni prava:

- uloga znanosti u izradi propisa,

- uloga znanosti u tumačenju propisa,

- uloga znanosti u predlaganju supstancijalne izmjene propisa $\mathrm{i}$

- uloga znanosti u predlaganju sasvim novih putova razvoja prava.

Ni kodifikacije građanskog prava ni ostali propisi građanskog prava ne mogu se donijeti bez sudjelovanja znanstvenika. Oni u pravilu daju i osobni pečat tomu, a

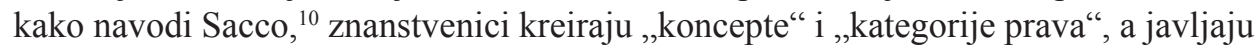
se i u ulozi profesora prava gdje ,indoktriniraju“ buduće pravnike i suce o sadržaju prava. Slično se može reći i za tumačenje (interpretaciju) propisa. Kod toga, međutim postoje dvojaki problemi: stariji propisi (napose građanske kodifikacije 19. stoljeća) su već „protumačene“, a novi se propisi često mijenjaju ili prilagođavaju dnevnim interesima što otežava svako ozbiljno tumačenje. Izmjena propisa (de lege ferenda) nije samo kritika propisa nego i prijedlog za iznalaženje boljih rješenja. Ni u općem pa tako ni u građanskom pravu nije sve „riješeno“ i sve „,izmišljeno“ $i$ ta je uloga znanosti

6 Ivan Padjen, Metodologija pravne znanosti: pravo i susjedne discipline (Rijeka: Pravni fakultet, 2015.), 62.

7 Radomir Lukić, Metodologija prava (Beograd: Srpska akademija nauka i umetnosti, 1979.), 3.

8 Važeći Ustav RH donesen je 2010. god., dakle prije ulaska RH u Europsku uniju. Nužno je (tu se kasni) nadopuniti odredbu o izvorima europskoga prava (tako to, npr. za Italiju predlaže Galgano, Diritto privato, 30).

9 Lukić, Metodologija prava; Padjen, Metodologija pravne znanosti: pravo i susjedne discipline, odnosno „metodologija pravne znanosti“ bile su na domaćem pravnom prostoru dugo zanemarivane. Zasluga je teorije i filozofije prava da su ove kategorije dobile važno mjesto u ukupnoj strukturi prava.

10 Sacco, Digesto civile, 1. 
vrlo dragocjena u razvoju prava, ali i u razvoju društva općenito.

Četvrta uloga znanosti prava spada u vrlo sofisticiranu zonu filozofije prava. ${ }^{11}$ To zapravo nije znanost (,,jer je znanost ono što se vidi, mjeri, dotiče, provjerava“) nego „meta-znanost“ gdje su i metode stvaranja potpuno drukčije (intuicija, nadahnuće, otkriće, aksiologija).

U prve dvije od spomenutih uloga znanost građanskog prava u Hrvatskoj svakako sudjeluje. Više u stvaranju nego u tumačenju propisa. Treća je dimenzija puno slabije razvijena, a četvrte (filozofska) gotovo da i nema. Jer, predlaganje novoga prava, odnosno novih dijelova (instituta) prava ne samo da je znanstveno teško, nego vrlo često zahtijeva i sukob s političkom vlašću kojeg znanost rijetko prihvaća.

U tu opću „lamentaciju“ o povijesnom gledanju na ulogu znanosti građanskog prava kao izvora toga prava možemo dodati i to da je i razvoj građanskopravne znanosti bio vrlo spor. Sigurno je to rezultat upravo prethodno navedene činjenice da su se ,pravo“ i ,pravna znanost“" već zarana tretirali kao određeni pravni sinonimi. I na to je ukazao Lukić govoreći o razvoju metodologije prava, ${ }^{12}$ ali mutatis mutandis to se odnosi i na čitavo pravo uključujući tu i građansko pravo koje je u povijesti dugo figuriralo kao ,prvo“ pravo. Lukić navodi i to da pravo taj povijesni nedostatak nastoji popraviti „hitnim“ uvođenjem novih metoda (kibernetika, informatika), ali da to neće moći „pokriti“ gotovo poraznu činjenicu da se kroz dugu povijest pravna znanost sporo razvijala, a da su tehničke znanosti ,galopirale“ do neshvaćenih dimenzija razvoja.

Gledano pod optikom nekih bitnih standarda u općoj znanosti koja je naglašavala istu temeljnu zakonomjernost u prirodi i društvu. ${ }^{13}$ Navedena ocjena Lukića zahtijeva određeno razmišljanje. Prvo, ipak nije potpuno točno da su tehničke znanosti otišle jako daleko u razvoju a da je prije toga bila ,pustoš“. Treba, npr. samo vidjeti egipatske, grčke, rimske, bizantske itd. građevine koje ne samo da ne zaostaju za današnjima nego su u mnogim elementima bolje i kvalitetnije. Drugo, ako i jesu tehničke znanosti imale nešto brži razvoj, to nije moglo biti bez određene uloge društvenih znanosti koje su kreirale propise i stanja u društvu pogodna i za tehnički napredak odnosno tehničke inovacije. I, treće, „mjerilo“ dinamike i tempa razvoja društvenih i prirodnih znanosti ipak nisu ista i vrlo je dvojbeno (i zapravo netočno) reći da suvremena znanost građanskog prava od rimskog vremena nije ,izumila“ ništa novoga.

Sve navedeno svakako ne negira temeljnu konstataciju da je upravo građansko

11 Lukić, Metodologija prava, 46-53. Filozofija prava (pa tako i filozofija građanskog prava) nije znanost $u$ tradicionalnom smislu riječi; ona je meta-znanost (znanost o znanosti) i nadilazi postojeće pravo. Njena je zadaća ,gledati iza ugla“, tj. tražiti i predlagati nove, bitne puteve prava. To je mnogo više od maksime „de lege ferenda“. Slično navodi i Padjen, Metodologija pravne znanosti: pravo i susjedne discipline, 129-131.

12 Lukić, Metodologija prava, 30-31.

13 U povijesti opće znanosti napose su se veliki umovi, kakvi su bili Kepler i Kant, zalagali za jedinstvo prirodnih i društvenih znanosti, polazeći od temeljnog stajališta da i u prirodi i u društvu vrijede u osnovi iste zakonitosti. Na konkretnom planu kao što je sveučilišno obrazovanje to bi zahtijevalo isti sustav studiranja. Praksa, posebno naša domaća, to važno pravilo ipak ne slijedi ili ga ne slijedi dostatno. 
pravo u svojoj dugoj povijesti zanemarivalo vlastitu znanost i nije u njoj vidjelo važan izvor građanskog prava. Zanimljive pojave, gotovo pravi preokret $\mathrm{u}$ tom smislu, nalazimo u vrlo relevantnoj i suvremenoj talijanskoj literaturi građanskoga prava. Već je spomenuti Lipari u navedenom, zaista „maestralnom“ znanstvenom radu, vrlo određeno rekao da znanost građanskog prava ne samo da nije relevantan izvor građanskog prava (ili da je to samo u vrlo malom i sporednom obimu) nego je njegov prvi i najvažniji izvor jer sudac primarno sudi prema svom znanju i shvaćanju prava. ${ }^{14}$ Lipari izjednačuje važnost sudske prakse i pravne znanosti (otuda i naziv njegova rada) $i$ ističe novi fenomen ,statalizacije“ i znanosti i prakse u smislu da bi se one „stopile“ u jedan jedinstven pojam. Sacco ${ }^{15}$ ističe ,profesorsku vlast“ (tal. potere dottorale). Profesori (znanstvenici) obrazuju studente prava, pišu knjige iz kojih oni uče, a pišu i komentare propisa na temelju kojih bivši studenti prava kao suci sude. Teško je reći koliko će ovaj „povijesni zaokret“ u shvaćanju pravne znanosti kao izvora građanskog prava prevladati, ali se čini da i nije riječ o „zaokretu“ (ili „preokretu“) nego o pravilnoj konstataciji stanja koje već dugo postoji, da sudac stvarno sudi prema svom shvaćanju prava, po onome što je naučio na studiju i po znanju koje je (eventualno) i nakon studija stekao. Možemo tako zaključiti vrlo zanimljivi fenomen: važnost znanosti građanskog prava kao izvora građanskog prava varira od minimiziranja (ili čak potpunog nijekanja) do maksimalizacije u smislu da je ona prvi i najvažniji izvor građanskog prava.

Na kraju ovog dijela rada valja spomenuti i neke probleme pravne konvencije. Premda je u prethodnom dijelu rada to (nekako „usput“) rečeno, valja naglasiti da pojam i izraz ,izvor prava“ valja shvatiti kao formalni izvor prava (lat. fontes iuris cognescendi) koji se upućuje svim adresatima prava (svim fizičkim i pravnim osobama), ali (i napose) sucu koji je u položaju prava i obveze razriješiti određeni sporan građanskopravni odnos. Sudac tako dobiva pravo i obvezu pratiti znanost građanskog prava, ali i opću znanost jer, kako ističe Lipari, suvremeno građansko pravo nije primjenjivo bez dimenzije općeg i građanskog morala koji su u stalnoj evoluciji, a „razbacani“ su po opsežnoj i vrlo heterogenoj literaturi. ${ }^{16}$ Sudac ne mora biti samo „potrošač“, samo „korisnik“" znanosti građanskog prava on, naprotiv, može biti i njezin aktivni stvaratelj, razmjerno tomu koliko mu primarni posao suđenja to dopušta.

Pravo i pravnici jedna su od najstarijih profesija u razvoju čovječanstva. Pravnici (napose suci) vrlo djelotvorno sudjeluju u razvoju društva, tradicionalno zauzimaju vrlo visokom položaju u sustavu vlasti i to je povoljna okolnost i za ostvarivanje

14 Lipari, Dottrina e giurisprudenza quali fonti integrate del diritto, 296.

15 Sacco, Digesto civile, 1-2.

16 Lipari, Dottrina e giurisprudenza quali fonti integrate del diritto, 303. Valja podsjetiti da u građanskom pravu moral ima veliku ulogu, da je jednim dijelom sastavni dio toga prava (nevaljanost pravnih poslova, dobra vjera u ugovornom pravu, neimovinska šteta, pojam osobnosti u neimovinskom dijelu građanskog prava itd.). Građansko pravo ovu dimenziju morala ima od svojih početaka. To se odnosi i na prvu definiciju prava koju je dao veliki rimski pravnik Ulpian, Iuris prudentia est divinarum atque humanarum rerum notitia, iusti atgue iniusti scientia (Digesta, Knj. I., 1,1,10,2 ). 
ciljeva pravne znanosti. ${ }^{17}$ Vladavina prava (engl. the rule of law) jedno je od vodećih pravnih načela razvijenog demokratskog svijeta, a ostvarivanje toga cilja nije moguće bez visoke uloge znanosti građanskog prava, odnosno prava uopće. U tom smislu mora postojati i jedno izvorišno, središnje mjesto koje će odašiljati poruke znanosti. Tradicionalno su to sveučilišta (odnosno njihovi fakulteti), bez obzira na svjetsku krizu sveučilišta pa čak i otvorena pitanja jesu li sveučilišta više uopće potrebna. ${ }^{18}$ Sveučilišta odnosno pravne fakultete, vjerojatno, valja modernizirati i osvježiti. Više ih vezati za život i praksu i (iznad svega) do kraja izložiti znanstvenoj domaćoj i stranoj konkurenciji. No, uloga sveučilišta (fakulteta) u razvoju znanosti prava mora ostati prva i avangardna. Ne dogodi li se to, nužno slijedi bitan pad razine znanosti građanskog prava, a (posljedično) i građanskog prava u cjelini. Potere dottorale, kako ga naziva Sacco, nužan je uvjet plodonosnoga razvoja građanskog prava i njegove znanosti. No, ta ,profesorska vlast“، nije neka feudalna povlastica, nego mora biti preoblikovana u predano služenje općem dobru na načelima znanstvene izvrsnosti i moralne čestitosti.

\section{NEKA POSEBNA PITANJA PRIMJENE ZNANOSTI GRAĐANSKOG PRAVA KAO IZVORA GRAĐANSKOG PRAVA}

Ako je, dakle, građanskopravna znanost važan izvor građanskog prava, ostaje nam zadaća razložiti bitne aspekte takva zaključka koji će i sam zaključak dodatno osnažiti i potvrditi.

\subsection{Znanost građanskog prava je „posredan izvor građanskog prava“?}

Riječ,,posredanizvor"tradicionalnonalazimouliteraturibivšegajugoslavenskog, odnosno sada hrvatskoga prava. Riječ ,posredan“ rabe Stojanović ${ }^{19}$ i Gams. ${ }^{20}$ Vodeći hrvatski autori građanskog prava Klarić i Vedriš rabe izraz „neizravan“, 21 što je pojam kojeg, npr. koristi i Sacco. ${ }^{22}$ Svi su ti izrazi jezični i pravni sinonimi i odražavaju u osnovi isto gledanje na građanskopravnu znanost kao mogući izvor građanskog prava.

Slabost je takva pristupa, međutim, u tome što znanost građanskog prava stavlja u zonu nekog manje važnog, sporednog pa čak i manje poželjnog izvora prava. Ovo, čini se, nije točno ili barem nije do kraja točno. Sudac, kako god presuđuje, uvijek primjenjuje znanost građanskog prava odnosno sudi tako kako po svom znanju prava primjenjuje određene propise i određene institute građanskog prava. „Posrednost“, odnosno ,indirektnost“ može doći do izražaja samo ako sudac može (hoće) primijeniti

17 Padjen, Metodologija pravne znanosti: pravo i susjedne discipline, 134.

18 Padjen, Metodologija pravne znanosti: pravo i susjedne discipline, 215.

19 Stojanović, Uvod u građansko pravo, 31.

20 Gams, Uvod u građansko pravo, 87.

21 Petar Klarić i Martin Vedriš, Građansko pravo: Opći dio, stvarno pravo, obvezno i nasljedno pravo (Zagreb: Narodne novine, 2006.), 23. Slično tvrdi i Vladimir Vodinelić, Građansko pravo - Uvod u građansko pravo i Opšti deo građanskog prava (Beograd: Pravni fakultet Univerziteta Union, 2012.), 121.

22 Sacco, Digesto civile, 2. 
neko specifično stajalište pravne teorije, gdje može birati između mišljenja različitih autora i opredijeliti se za jedno (ili nijedno) od njihovih mišljenja. Tu se doista osjeća „persuazivna snaga“ pravne znanosti ${ }^{23}$ odnosno to da će sudac primijeniti neka stajališta pravne znanosti samo ako ga je argumentacija konkretnoga znanstvenika uvjerila da sukladno s tim može utemeljiti svoju presudu. Sudac u tom slučaju bira između ponuđenog, „važe“ što mu odgovara i što bolje „pokriva“ određen činjenični i pravni problem. Ne može se reći da se on tada pojavljuje u ulozi nekakva recenzenta znanstvenog rada, ali svakako sudac kritički vrednuje odnosne znanstvene radove. Takav položaj suca otvara i jedno novo pitanje: Je li kompetentan vršiti izbor između pojedinih autorskih djela te neke od njih prihvatiti, a druge odbiti?

Profesori prava, ma koliko pojam ,profesorske vlasti“ (tal. potere dottorale) nije bespredmetan, nemaju ius respondendi ${ }^{24}$ i nema osnove za zaključak da su oni eo ipso veći poznavatelji građanskog prava od suca koji vodi konkretan spor. Stoga se, a svakako i zbog toga što znanstvenici ne znaju relevantne činjenične i pravne aspekte spora, ne bi moglo danas braniti gledište da bi sudac morao prihvatiti stajalište bilo kojeg pravnog znanstvenika. Sudac je, uostalom, Zakonom jedini ovlašten presuditi sporne stvari. Važeći Zakon o sudovima $\mathrm{RH}^{25} \mathrm{u}$ čl. 5. samo ponavlja Ustavni tekst o izvorima prava. Zakonski tekst je utoliko bolji što (pravilno) međunarodne ugovore navodi prije Zakona, odnosno prije međunarodnih ugovora stavlja ,stečevine Europske unije“, ali je ostala nejasna i „sudbina“ pravne znanosti. Nismo sigurni bi li se znanost građanskog prava mogla ,prokrijumčariti“ kroz ,pravne stečevine Europske unije“, barem za europsko ako ne i za domaće pravo. Ustavno dvojbeno ostaje sadašnja formulacija čl. 5. Zakona o sudovima s obzirom na to da tekst Ustava nije izmijenjen (ne poznaje „stečevine Europske unije“ i ne navodi međunarodne ugovore prije zakona).

Što je znanost građanskog prava, tko su znanstvenici građanskog prava i kako se (i gdje) djela takve znanosti pronalaze?

Sasvim kolokvijalno, i bez posebnih znanstveno-metodoloških pretenzija, valja reći da građanskopravna znanost čini sve što je o građanskom pravu napisano, odnosno što se o njemu piše. To su visokoškolski udžbenici, pravna djela (knjige) posvećene nekom posebnom problemu, pravne enciklopedije, članci u znanstvenim časopisima itd. Suvremena informatizacija omogućava bitno lakše pronalaženje ove literature ali ne rješava suštinu problema jer većina relevantnih znanstvenih djela nisu (pa ni ne mogu biti) na ,internetskom“ raspolaganju.

Pojam znanosti (teorije, literature) građanskog prava ne podrazumijeva samo nacionalnu literaturu. Sada, kada smo i formalno u Europskoj uniji, obveza praćenja i poznavanja građanskopravne literature nužno se proširuje i na europsku

23 „Perzuazivno“ je talijanizam. Koristi ga izravno Sacco, Digesto civile, 2, a može se prevesti kao „snaga uvjerljivosti“, odnosno, u kontekstu ove rasprave, kao uvjet pod kojim će sudac koristiti znanost prava u presudi.

24 Ius respondendi je, kako je u pravničkom svijetu već i općepoznato, institut rimskoga prava kojim je car (lat. ex autoritatem principis) nekim (samo nekim) pravnicima dodjeljivao ovlast davanja za pretora obvezujućih pravnih mišljenja. U kasnijoj povijesti toga već nije bilo pa se danas spominje kao nešto što pripada dalekoj povijesti.

25 Narodne novine, br. 28/13., 33/15., 82/15. i 82/16. 
literaturu. ${ }^{26}$ Prateći problem pritom je poznavanje stranih jezika. Suci (a i ostali pravnici) iz domene civila tu nisu baš „najjači““. Domaći pravni fakulteti su, doduše, u svoje nastavne planove uveli i strane jezike ali to, u pravilu, nije razina znanja koja omogućuje kompetentno praćenje strane literature. ${ }^{27}$

Znanstvenici građanskog prava nisu samo profesori prava, premda (napose na europskom kontinentalnom prostoru) jesu prvi predstavnici znanosti građanskog prava. Vrlo relevantne stvari mogu napisati i suci, odvjetnici i drugi pravnici civila. ${ }^{28}$ U tom smislu valja doista napustiti logiku iz basne o rodi i lisici ${ }^{29}$ te razvijati novu praksu sinergije ,čiste“ znanosti i znanstvenog pisanja pravnih praktičara. ${ }^{30}$

\subsection{Mogući načini korištenja građanskopravne literature u sudskim presudama}

Opći je zaključak ovoga rada da sudac, sudeći u određenoj građanskopravnoj stvari, uvijek primjenjuje znanost građanskog prava budući da sudi po svom znanju prava stečenog tijekom studija i u svom kasnijem profesionalnom razvoju. ${ }^{31}$ Stoga se od suca ne može tražiti dokazivanje (pokazivanje) otkud njegovo znanje o posjedu, vlasništvu, neimovinskoj šteti, oporučnom raspolaganju itd. Tada sudac, dakle, primjenjuje svoje znanje prava, ono što je postalo njegov intelektualni patrimonium i u tom slučaju on u svojoj odluci nije obvezan navoditi izvore tih znanja. No, kada sudac (što u praksi, nažalost, vrlo rijetko čini) želi primijeniti neki specifičan stav pravne teorije, otvara se daljnji problem kako to može ili treba činiti. Tu, naime, prelazimo na zonu autorskog prava i onda - poštujući moralna prava autorstva kao prava osobnosti, ${ }^{32}$ sudac treba navesti ime autora od kojeg je preuzeo određen pravni

26 Tu bi, moguće, bilo prezahtjevno (i praktički nemoguće) pratiti pravnu literaturu svih država članica Europske unije kao i same Europske unije. Razlozi praktičnosti će zahtijevati da se to reducira samo na najveće pravne škole EU-a (njemačku, francusku, španjolsku, talijansku).

27 U tom smislu bit će nužno organizirati odgovarajuće službe prijevoda. Najbolje bi bilo da se stvori jedan posebno osposobljen centar u Europskoj uniji.

28 Činjenica je da se suci (a i ostali pravnici praktičari) vrlo rijetko i malo pojavljuju kao autori stručnih i znanstvenih radova. Razlozi su mnogostruki, svakako potencirani i stvorenim stereotipom da je pisanje za profesora, a suđenje za suce.

29 U poznatoj basni o rodi i lisici, kako je poznato roda pozove lisicu u goste i počasti je jelom u visokoj i uskoj posudi (tako da svu ponuđenu hranu pojede roda), no u uzvratnom posjetu slično postupi i lisica - ponudi joj jelo na niskom i plitkom tanjuru s kojeg ona vrlo brzo sve „očisti““.

30 U početcima hrvatske državne neovisnosti Vrhovni sud RH izdavao je jedan vrlo zanimljiv stručno-znanstveni časopis (Iudeks) koji je mogao primjereno sjediniti teoriju i praksu sudskoga prava. Šteta što je, zbog nekih ,adolescentnih“ pogrešaka, a i osobnih razilaženja, časopis ugašen.

31 Stajalište Sacca (Digesto civile) je da su nastava na pravnim fakultetima (predavanje, rad u manjim grupama), ne samo knjige, najbolje i zapravo jedino pravno sredstvo pozitivne znanstvene „indoktrinacije“ budućih pravnika. Šteta, doista, što ti oblici nastave sve manje znače na našim fakultetima.

32 Moralno pravo autorstva (pravo autora biti priznat kao autor djela) sastavni su dio prava osobnosti. Tako, npr. navodi: Ivan Henneberg, Autorsko pravo (Zagreb: Informator, 1996.), 105-110, a u europskoj literaturi prava osobnosti to je posebno naveo Adriano De Cupis, Diritto della personalita (Milano: Giuffre, 1982.), 396-427. 
stav i naziv toga djela. ${ }^{33}$

Kod svega ovoga potreban je i određen oprez. Neki sustavi (npr. njemački) favoriziraju navođenje pravne znanosti u sudskim odlukama, ali ima i suprotnih primjera (tako se, npr. u st. 4. čl. 118. Zakona o izmjenama talijanskoga Zakona o parničnom postupku izričito brani da sudac u svojoj odluci navodi znanstvena djela). Prvi (njemački) stav očito polazi od opće pozicije da sudac sudi „po pravu“ (ne, dakle, samo po zakonu); drugi (talijanski) stav želi suca držati isključivo na zakonu. Plediramo usvajanje navedenoga njemačkog stava, uz dodatni razlog da naš ZPP ne brani pozivanje na znanje prava, a neizravno ga čak i omogućuje kada govori o obvezi suca da se u obrazloženju odluke osvrne i na navode stranaka koji mogu biti i čisto pravne naravi (st. 4. čl. 338. ZPP). Pritom, ako nekoga autora doslovno citira, mora to staviti pod navodne znakove; ${ }^{34}$ ako se pak korištena literatura samo prepričava, navodnici nisu potrebni, ali ostaje obveza navođenja autora i njegova djela.

Profesori prava su, barem na europskom kontinentalnom prostoru, ,primarni““ znanstvenici prava. Anglosaksonske tendencije su, kako je općepoznato, drukčije. No, doista nije riječ se o nikakvom profesorskom monopolu, ponajmanje o zajamčenom monopolu, pa znanstvena djela koja će sudac u presuđivanju koristiti mogu pisati i drugi pravnici (po prirodi stvari, to se posebno očekuje od sudaca najviših sudova. ${ }^{35} \mathrm{U}$ tom slučaju sudac ne citira suca nego pravnoga znanstvenika.

\subsection{Važnost sudske presude koja sadrži, odnosno ne sadrži neko stajalište građanskopravne znanosti}

Sociološka je činjenica da naši suci iznimno rijetko u obrazloženjima svojih odluka navode stavove pravne teorije na temelju kojih su donijeli konkretne odluke. Razlozi za to su višestruki: Teorija (znanost) previše je udaljena od stvarnog života i ne može služiti kao orijentir za suđenje, praksa zanemaruje teoriju kao suvišnu i nepotrebnu, nema kulture i atmosfere korištenja znanosti (napose one inozemne) u suđenju. Treba žaliti što je tome tako (jer to dosta umanjuje kvalitetu presuda), ali samo po sebi to nije povreda postupka i ne može se zbog toga uspješno pobijati konkretnu sudsku odluku. Korištenje nekoga specifičnog djela građanskopravne znanosti je mogućnost, pravo, ali ne i obveza suca.

Zakon o parničnom postupku ne obvezuje suca na korištenje (i navođenje) pravne literature u obrazloženju odluke ${ }^{36}$ i to je izraz stajališta da ni stranka u tužbi

33 Pritom je posebno pitanje u kom obliku to činiti (u tekstu ili kao fusnotu?).

34 Čini se da su to jezično-pravopisna, a ne pravna pitanja, premda je u logici poštovanja moralnog autorskog prava bliže da se doslovni prijenos autorskih riječi uvijek stavi pod navodnike.

35 Ni suci najviših sudova u RH nisu posebni „gosti“" naših stručnih i znanstvenih časopisa. Bilo bi više nego dobro otvoriti prikladne „kanale“ suradnje profesora prava i sudaca najviših sudova (za sada jedni i drugi čvrsto zatvaraju svoja ,vrata“).

36 Vodeća domaća postupovna teorija, vidi Siniša Triva i Mihajlo Dika, Građansko parnično procesno pravo (Zagreb: Narodne novine, 2004.), 412, to objašnjava načelom iura novit curia po kome sud zna i mora znati pravo. Ako sud mora znati pravo, u obrazloženju svoje odluke mora navesti i sadržaj toga prava (čl. 338. st. 4. ZPP-a). ZPP na tom mjestu (vezano za pravnu osnovu spora gdje se može raditi i o primjeni znanosti prava) spominje obvezu suda samo ,ako je to potrebno" i samo o ,stavovima stranaka“. 
ne mora navesti pravnu osnovu svoga zahtjeva (argument iz st. 3. čl. 186. ZPP). Sudac pokazuje povećano znanje prava kada se poziva i na određeno mišljenje pravne znanosti, ali ne može isključivo (jedino) na tome temeljiti svoju presudu. ${ }^{37}$ Znanost je građanskog prava izvor građanskog prava, ali u strukturi izvor prava (Ustav, zakoni ...) po ,prirodi stvari“ zakon ima prednost i ZPP s pravom navodi da se od izvora prava samo zakon mora navesti i uvijek se na zakonu sudska odluka mora temeljiti. Pozivanje na pravnu znanost stoga je prihvatljivo samo kao dodatno sredstvo, kao „pomoć“ koja pojačava argumentaciju i stajalište suda da je zakon dobro primijenjen.

\section{RAZVOJ ZNANOSTI GRAĐANSKOG PRAVA I OBVEZA SUDACA NA NJEZINO PRAĆENJE}

Suvremeni život na svim područjima društvenoga života otvara svakodnevno nova pitanja, takva kakva prije ne samo da nisu bila moguća nego često nisu bila ni zamisliva. U građanskom pravu bilježimo tako neke potpuno nove dijelove (pravo osobnosti, medicinsko pravo, medijsko pravo, sportsko pravo itd.) a osobit je novum „konfrontacija“ s europskim konvencijskim i komunitarnim pravom. Neke od relevantnih instituta sudac upozna tijekom studija ali se drugi instituti pojavljuju kasnije (kada on već djeluje u profesionalnom životu) i to onda otvara pitanje obveza i načina praćenja novoga u znanosti prava, a i pravnom životu općenito.

Zakon o sudovima ${ }^{38}$ u st. 3. čl. 93. obvezuje suca na „stalno sudačko usavršavanje“ ali pod tim podrazumijeva (samo) sudjelovanje „u programima obrazovanja i usavršavanja Pravosudne akademije ili Europske mreže centara za stručno usavršavanje pravosudnih dužnosnika“. ${ }^{39}$ Sve drugo ovisi isključivo od dobre volje suca (arg. iz st. 3. i 4. Zakona). Načelno gledano stalno (permanentno) obrazovanje sudaca (a i ostalih pravosudnih dužnosnika) može varirati od jednostavnih, tzv. radionica pa do doktorskog studija. Prvi oblici čine se prejednostavnim (i ne doprinose postizanju željenog cilja), dok doktorski studij (ma koliko one najvrijednije od toga ne valja odvraćati) zahtijeva preveliki vremenski i intelektualni angažman i pitanje je koliko sudac, uz svoj redoviti posao može stizati još i na ovaj najviši izraz usavršavanja. ${ }^{40}$ Neka opća iskustva pokazuju da je najbolji način stalne izobrazbe sudaca samoobrazovanje, da sudac, dakle, svojom voljom i inicijativom prati razvoj znanosti prava. Stoga je nužna odgovarajuća atmosfera u samom sudstvu i tu osobitu zadaću imaju viši, odnosno najviši sudovi kao kreatori i poticatelji na praćenje pravne znanosti.

Znanje građanskog prava pojedinih sudaca prati se uglavnom samo statistički (po broju potvrđenih, ukinutih i preinačenih odluka), a vrlo je dvojbeno može li

37 Takva bi odluka suda bila apsolutno bitna povreda postupka (čl. 354. st. 2. t. 11. ZPP-a), ne samo relativno (čl. 354. st. 1. u svezi s čl. 338. st. 4. ZPP).

38 Narodne novine, br. 28/13., 33/15., 82/15., 82/16., 67/18.

39 Odredba zvuči dosta ,jako“, ali praktično je dosta dvojbena. Nije jasno zašto bi sudjelovanje u programima Pravosudne akademije bilo jamstvo stvarnoga zanimanja za znanost prava, a Europsku mrežu treba tek razviti.

40 I o tome bi valjalo bolje razmisliti. Jedan broj sudaca uvijek želi pristupiti razini doktorskoga studija pa treba pronaći prihvatljivi odnos između želja i mogućnosti. 
sučevo znanje građanskog prava bilo koje tijelo državno-sudbene vlasti naknadno provjeravati. ${ }^{41}$ Suce treba primarno poticati na praćenje znanosti prava kroz instancijsko odlučivanje. Žalbeni sudovi, odnosno revizijski sud jedino su ovlašteni ocjenjivati stručnu vrijednost pobijene sudske odluke, a time i sučevo stručno poznavanje prava. Razumije se da takvo djelovanje viših sudova pretpostavlja i povećano stručnoznanstveno znanje sudaca tih sudova.

Potrebu za stalnim stručnim usavršavanjem treba razvijati kod svih pravnika koji dolaze u doticaj s građanskim pravom (osim sudaca, tu su odvjetnici, državni odvjetnici, ${ }^{42}$ korporativni pravnici, bilježnici). Nije, naime opravdano očekivati nekakav opći i pravni boljitak ako samo suci „povuku“ naprijed, a svi ostali stoje „zabetonirani“ u prošlosti, odnosno prošlom znanju. S druge strane, i građanskopravna znanost, da bi bila poželjni objekt praćenja, mora biti aktualna, pravno atraktivna i lako dostupna. Čini se da u rečenom smislu danas postoje ozbiljni nedostatci na obje strane. Njihova se sinergija tu i tamo spominje, ali uglavnom samo deklarativno i sasvim prigodničarski. Istinskoga zahvata nema, premda se mora priznati da se zaokret ove vrste ni ne može izvesti ni brzo ni bez teškoća. Okvir Europske unije bi ipak trebao biti jači poticaj u ovome pravcu.

\section{OSVRT NA NEKE AKTUALNE ASPEKTE ULOGE I RAZVOJA ZNANOSTI GRA円ANSKOG PRAVA}

Građanskopravna znanost (kao znanost prava uopće) ima tradicionalnoga konkurenta u političkoj vlasti. Te dvije vlasti (pravna i politička) imaju isti objekt djelovanja (društva), ali različite ciljeve i načine djelovanja. Tu započinje proces kojeg Padjen s pravom naziva marginalizacijom prava ${ }^{43}$ ali to je proces koji je manjeviše svugdje i s kojim se pravna vlast ipak zna nositi. U nas je u tom smislu situacija ipak utoliko teža što je u bivšoj državi, odnosno bivšem sustavu taj pritisak političke vlasti bio mnogo jači negoli u demokratskom svijetu i mi moramo uložiti dodatne napore da svijet prava oslobodimo tutorstva politike.

Druga „faza“ marginalizacije prava nastaje u „kooperaciji“ politike i institucija pravne znanosti. Mislimo tu na (vrlo često) olako otvaranje novih studija, sveučilišta i fakulteta ${ }^{44}$ gdje, neminovno, dolazi do pada kvalitete znanosti. Nije, naime, moguće

41 Poznato je, npr. da Državno sudbeno vijeće provjerava i stručno znanje kandidata za mjesto sudaca (pišu se ogledni primjerci presude, a vjerojatno se radi i ,usmena“ provjera). To je vrlo dvojbeno, a ponekad je i neugodno (npr. kada se na mjestu suca kandidira i sveučilišni profesor prava).

42 Kod državnih je odvjetnika, čak hitna, nužnost većega poznavanja građanskog prava. Gospodarska kaznena djela ne mogu se razumjeti bez poznavanja građanskog prava (ništetnost pravnih poslova, ovlaštenje za zastupanje, odgovornost trgovačkih društava, odgovornost za štetu, sklapanje i trajanje ugovora itd.). Pojašnjenje je lošega tijeka većine vrlo razvikanih kaznenih postupaka u RH velikim dijelom baš u tome.

43 Padjen, Metodologija pravne znanosti: pravo i susjedne discipline, 26.

44 Očita je tendencija širenja mreža sveučilišta i fakulteta. Nakon raspada bivše federacije ponegdje se u tome jednostavno pretjeruje. Premda nešto manje, ni Hrvatska nije izbjegla tu „bolest“. 
odjednom „stvoriti“ toliki broj kompetentnih sveučilišnih nastavnika koji će uspješno opsluživati povećani broj fakulteta $\mathrm{i}$ studenata. $\mathrm{S}$ tim u svezi nisu, nevažna ni financijska pitanja (istu masu novca dijeli povećani broj korisnika), a ostaje i bitno pitanje nekontroliranog širenja mreža visokoškolskih institucija u uvjetima kada nam broj stanovnika pada, a društveni proizvod ne raste ili neznatno raste.

„Izvanredni studiji“, „studiji uz rad“, „bolonjski studij“ i tome sl., poseban su udar na kvalitetu znanosti, jer omogućuju stjecanje „brzih“ diploma, iste pravne vrijednosti, ali bez pohađanja istoga programa nastave. U tim se situacijama može postaviti pitanje ustavnosti propisa koji omogućuju „brze“ diplome. Moglo bi se govoriti o povredi ustavnog prava na jednakost građana (čl. 14. Ustava RH).

Najgrublji nasrtaj na pravo i znanost prava nalazimo u pojavama vezanim za falsificiranje diploma pravnih fakulteta, i što je puno gore od toga, za stjecanje diploma čistom korupcijom (kupovanje diploma, bez studiranja). To nije samo marginalizacija prava i pravne znanosti, to je čisto sramoćenje prava i ujedno indikator određenih upravo patoloških procesa u društvu. Znak je to visoke birokratiziranosti društva koje traži „papire“, ne traži i ne treba mu znanje. „Papiri“ imaju sve veću tržišnu cijenu, znanje se potpuno gazi. Ako doista osoba koja je doslovno kupila diplomu prava nesmetano obavlja poslove pravnika, pravne fakultete, doslovno, valja zatvoriti kao suvišne i nepotrebne. Takav se scenarij ne smije dopustiti i valja vjerovati da se on ni neće dogoditi. Nužno mu je, međutim, energično stati na kraj, što neće biti lako i što će ponekad zahtijevati vrlo osjetljive mjere. ${ }^{45}$

U hrvatskom društvu valja obnoviti duh optimizma i - napose - duh kulture općeg interesa. To će omogućiti toliko potreban opći boljitak a na planu prava i znanosti prava stvoriti će temelje ne samo za otklanjanje opisanih aspekta marginalizacije i sramoćenja nego će ujedno razviti bazu za novi i kvalitetan uzlet.

U znanosti prava odnosno znanosti građanskog prava predstoji bitka za kvalitetu, za izvrsnost. Treba završiti priču o stihijskom širenju studija prava i broja studenata odnosno diplomiranih pravnika i usmjeriti se na istinsko stvaranje visokokvalitetnih pravnih stručnjaka koji će voditi važne poslove u hrvatskom društvu. To je imperativ koji vrijedi ne samo za obrazovanje pravnika nego i za znanost prava uopće.

\section{ZAKLJUČAK}

U građanskom pravu (a i u pravu uopće) postoji jedan popriličan apsurd: najmanje i vremenski najkasnije uređeno je ono što je tom pravu najbliže. Novije dokaze za ovu tezu nalazimo, npr. u razvoju prava osobnosti (i medicinskom pravu kao dijelu tog prava), gdje je čovjek kao stvaratelj prava zanemario da tim istim pravom zaštiti sebe, svoju osobnost. Još je jači dokaz u istom smjeru slučaj sa znanosti građanskog prava gdje i najveći autoriteti toga prava zanemaruju ili marginaliziraju važnost znanosti kao izvora građanskog prava.

Tek neke nove tendencije dovode do „rehabilitacije“ uloge i važnosti građanskopravne znanosti, i to čak u jednoj maksimalističkoj mjeri, da je znanost

45 Propise (i napose, praksu) nostrifikacije diploma s bivšega federalnog prostora treba podići na višu razinu pravne kontrole, bez obzira na eventualnu diplomatsku osjetljivost toga. 
prvi i najvažniji izvor građanskog prava. To se obrazlaže time što pravo (u njegovoj finalnoj funkciji arbitra u društvu) primjenjuje sudac, a primjenjuje ga sukladno sa svojim znanjem prava i onim stečenim tijekom studija i onim stečenim u kasnijem profesionalnom razvoju. Čini se da neki noviji procesi idu u tom pravcu. Doduše, ne uvijek prihvaćanjem samo znanosti nego (više) njezinim sjedinjavanjem sa sudskom praksom. To je proces koji, s jedne strane, podiže važnost znanosti prava kao izvora prava, ali ga, s druge strane može i kočiti jer praksa od znanosti uzima samo onoliko koliko joj je potrebno u danoj situaciji.

Izdizanje znanosti građanskog prava na razinu važnijega izvora građanskog prava otvara poseban razgovor o dva bitna pitanja; studijskom obrazovanju sudaca (a i ostalih pravnika) i njegovu kasnijem profesionalnom usavršavanju.

Treba se suprotstaviti još uvijek jakim tendencijama stihijskoga širenja fakulteta i studija i bitnu pažnju usmjeriti na kvalitetu i izvrsnost. Samo će u takvoj projekciji znanost građanskog prava dobiti svoju pravu i stvarnu ulogu. Na niskoj razini kvalitete pravnog studija znanost građanskog prava sama sebe uništava i postaje sudionik krajnje opasne tendencije da su pravni fakulteti samo mjesta gdje se tiskaju diplome, a ne rasadnici visokostručnih kadrova željnih pravnih znanja o pravu.

Samo kvalitetna znanost može stvoriti dobre građanske suce i pravnike i samo takvi stručnjaci mogu kreativno primjenjivati i dalje razvijati znanost prava. U Republici Hrvatskoj treba u tom smislu dati znanosti praksi novi zamah. Novi socijalni uvjeti, a napose članstvo u Europskoj uniji, morali bi biti taj nužni okvir za višu razinu važnost znanosti kao izvora građanskog prava. Danas doista prisustvujemo možda i svjetskoj krizi sveučilišta. „Trebamo li još uvijek sveučilište?“ za sada ipak daje odgovor da je sveučilište potrebno, ali samo u ulozi ustanove visokog obrazovanja. ${ }^{46}$ Onaj esencijalni istraživački aspekt kao da nestaje.

Sveučilište (pravni fakulteti) moraju zadržati ulogu par exellance, biti mjesto obrazovanja pravnika i razvoja znanosti prava, ali ne biti jedina mjesta tog procesa. Ova druga mjesta (koja u novim socijalnim uvjetima trebamo iznova odrediti) napose trebaju služiti procesu stalnog usavršavanja građanskih sudaca i građanskih pravnika uopće.

\section{LITERATURA}

1. De Cupis, Adriano. Diritto della personalita. Milano: A. Giuffrè, 1982.

2. Galgano, Francesco. Diritto privato. Padova: CEDAM, 1992.

3. Gams, Andrija. Uvod u građađansko pravo: Opšti deo. Beograd: Naučna knjiga, 1985.

4. Henneberg, Ivan. Autorsko pravo. Zagreb: Informator, 1996.

5. Klarić, Petar i Martin Vedriš. Građansko pravo: Opći dio, stvarno pravo, obvezno $i$ nasljedno pravo. Zagreb: Narodne novine, 2006.

6. Koziol, Helmut i Rudolf Welser. Bürgerliches Recht. 13. Aufl. Wien: Manz, 2006.

7. Larenz, Karl. Allgemeiner Teil des bürgerlichen Rechts. 8. Aufl. München: C. H. Beck, (1997).

8. Lipari, Nicolò. „Dottrina e giurisprudenza quali fonti integrate del diritto “. Jus civile br. 4 (2016.): 295-305.

46 Padjen, Metodologija pravne znanosti, 215. 
9. Lukić, Radomir. Metodologija prava. Beograd: Srpska akademija nauka i umetnosti, 1979.

10. Padjen, Ivan. Metodologija pravne znanosti: pravo i susjedne discipline. Rijeka: Pravni fakultet, 2015.

11. Palandt, Otto. Bürgerliches Gesetzbuch. 61. Aufl. München: C. H. Beck, 2002.

12. Sacco, Rodolfo. Digesto civile. 4 ed. Torino: Utet, 1991.

13. Stojanović, Dragoljub. Uvod u građansko pravo. Beograd: Prosveta, 1984.

14. Triva, Siniša i Mihajlo Dika. Građansko parnično procesno pravo. Zagreb: Narodne novine, 2004.

15. Vodinelić, Vladimir. Građansko pravo - Uvod u građansko pravo i Opšti deo građanskog prava. Beograd: Pravni fakultet Univerziteta Union, 2012. 


\section{Aldo Radolović*}

\section{Summary}

\section{THE LEGAL SCIENCE AS A SOURCE OF THE CIVIL LAW}

Civil law science in civil law itself is cited as a secondary, "indirect", almost less important source of civil law. Some recent tendencies, however, say the opposite - that the science of civil law is the primary source of civil law because the judge makes judgments according to the knowledge of law acquired during his studies and in later professional career. That is why talking about the civil law science as a source of this science is also a conversation about the education of lawyers at law faculties and the extension of this process after graduation. In the Republic of Croatia at this time we see significant problems in both directions and even a lag that would be desirable to overcome as soon as possible.

Keywords: law; civil law; science; science of law; science of civil law; sources of civil law; education of lawyers; law studies; education of lawyers and judges after study; application of civil law science in trial.

\section{Zusammenfassung}

\section{DIE RECHTSWISSENSCHAFT ALS QUELLE DES ZIVILRECHTS}

DieWissenschaft desZivilrechts wird imZivilrechtals sekundäre, ,,indirekte“oder weniger wichtige Rechtsquelle angegeben. Neue Tendenzen aber sprechen entgegen dieser Angaben - sie behaupten, nämlich, dass die Wissenschaft des Zivilrechts die primäre Rechtsquelle ist, weil der Richter im Einklang mit den während des Studiums und der beruflichen Fortbildung erworbenen Kenntnissen richtet. Deshalb ist die Diskussion über die Wissenschaft des Zivilrechts als Quelle dieser Wissenschaft gleichzeitig auch die Diskussion über Juristenausbildung an rechtswissenschaftlichen Fakultäten sowie auch über die Verlängerung dieses Prozesses nach dem Studium. In der Republik Kroatien tauchen jetzt wesentliche Probleme oder sogar Rückstände diesbezüglich auf, welche man baldmöglichst bewältigen sollte.

Schlüsselwörter:Recht; Zivilrecht; Wissenschaft; Rechtswissenschaft; Wissenschaft des Zivilrechts; Quellen des Zivilrechts; Juristenausbildung; rechtswissenschaftliches Studium;

* Aldo Radolović, Ph.D., retired judge at the Constitutional court of the Republic of Croatia, retired full professor of the University of Rijeka, Faculty of Law; radolovic47@gmail.com. 
Ausbildung von Juristen und Richtern nach dem Studium; Anwendung der Wissenschaft des Zivilrechts beim Richten.

Riassunto

\section{LA SCIENZA GIURIDICA QUALE FONTE DEL DIRITTO PRIVATO}

La scienza del diritto privato già nel diritto privato stesso viene indicata come una fonte accessoria, ,indiretta“ e pressoché residuale. Alcune nuove tendenze, tuttavia, affermano il contrario - e cioè come la scienza giusprivatistica sia la prima fonte del diritto privato poiché il giudice decide in base alla conoscenza che del diritto ha acquisito durante gli studi e successivamente nello sviluppo professionale. Di qui la constatazione che il dibattito circa la scienza del diritto privato quale fonte di questa disciplina è al contempo anche un dibattito sulla formazione dei giuristi nelle facoltà giuridiche, come anche sulla perpetuazione di tale processo formativo anche a compimento degli studi. Nella Repubblica di Croazia in questo momento su entrambi i versanti individuiamo dei problemi significativi, come anche una arretratezza che occorrerebbe quanto prima superare.

Parole chiave: diritto; diritto privato; scienza giuridica; scienza del diritto privato; fonti del diritto privato; formazione dei giuristi; studi giuridici; formazione dei giuristi e dei giudici a compimento degli studi; applicazione della scienza del diritto privato nel processo. 
